Gi respons på artikler gjennom artiklenes kommentarfelt på tidsskriftet.no.

Innleggene publiseres fortløpende på Tidsskriftets nettside og et utvalg

av innleggene publiseres også i papirutgaven i spalten «Brev til redaktøren».

Redaksjonen forbeholder seg retten til å foreta redaksjonelle endringer.

Forfattere av vitenskapelige artikler har tilsvarsrett, jf. Vancouver-gruppens regler.

\section{Re: Dagens studenter er fremtidens helseledere}

Tor-Arne Hegvik \& Eivind Alexander Valestrand påpeker i Tidsskriftet nr. 18/2016 at en rekke av problemene i dagens helsetjeneste skyldes ledere med dårlig legitimitet på grunnplanet, overdreven hang til å ville tekkes ledelsesnivået over, og svak lojalitet overfor den pasientrettede virksomheten (1). Det er utvilsomt riktig. Spørsmålet er hva som skal til for å endre dette.

Det kan i og for seg være en god idé å gi medisinstudenter lederopplæring, og for det jeg vet kan det godt tenkes at slik opplæring med hell kan gis ved de lærestedene Hegvik \& Valestrand foreslår. Men det vil ikke komme noe tjenlig ut av dette hvis man ikke starter med en grunnleggende drøfting av hvilke verdier fremtidens helseledelse skal bygge på og hvor fremtidens helseledere skal ha sin lojalitet.

Dessverre er leger på ingen måte immune mot å bli slike dårlige ledere. Siden Hegvik \& Valestrand nevner sykehusfusjonen i Oslo, er det på sin plass å minne om at leger (med lederutdanning) har stått sentralt i prosessene bak dette meget uheldige eksperimentet (2). På den annen side finnes det eksempler på glimrende helseledere som ikke har helsefaglig bakgrunn i det hele tatt (3).

Spørsmålet er derfor ikke så mye hvordan man skal få gitt leger (og medisinstudenter) ledelsesutdanning, som hvilke ledelsesidealer man ønsker å sosialisere fremtidens helseledere inn i. Helseledelse er nettopp ikke «business administration», men stiller andre krav. Mye ulykke er kommet ut av at man forsøker å styre den offentlige helsetjenesten etter kvasi-markedsøkonomiske prinsipper. Å sosialisere fremtidige leger inn $i$ en forfeilet ledelsesideologi allerede i studietiden, vil lett gjøre vondt verre.

\section{Torgeir Bruun Wyller}

t.b.wyller@medisin.uio.no

Torgeir Bruun Wyller (f. 1960) er professor i geriatri ved Oslo universitetssykehus og leder for Helsetjenesteaksjonen.

Ingen oppgitte interessekonflikter

\section{Litteratur}

1. Hegvik TA, Valestrand EA. Dagens studenter er fremtidens helseledere. Tidsskr Nor Legeforen 2016; 136: 1520

Slagstad R. Helsefeltets strateger. Tidsskr Nor Legeforen 2012; 132: 1479-85.

3. Tveito M. En ansvarlig tilrettelegger. Tidsskr Nor Legeforen 2015; 135: 1446-8

\section{Re: Norsk mammografiscreening - mange selvmotsigelser i evalueringen}

Tre dager før vår artikkel om selvmotsigelser i evalueringen av mammografiscreening i Norge ble publisert i Tidsskriftet (1) publiserte tidsskriftet New England Journal of Medicine (2) en artikkel som konkluderte stikk motsatt av hva Norges forskningsråd konkluderte i sin evaluering av det norske mammografiprogrammet. Den nye studien støtter fullt ut vårt syn. I Norge sier man at mammografiscreening har redusert dødeligheten av brystkreft med $20-30 \%$. I USA sier de at mesteparten av reduksjonen på 30\% skyldes bedre behandling (2). I Norge sier man at det er 15-20\% overdiagnostikk, mens forekomst av brystkreft (inkludert duktalt carcinoma in situ DCIS) er assosiert med en $75 \%$ økning i den aldersgruppen som inviteres til screening. Forskjellen mellom $15-20 \%$ og $75 \%$ forklares av Norges forskningsråd med forandring i eksponering for andre risikofaktorer enn mammografi (f.eks. bruk av hormoner mot plager i overgangsalderen). I USA konkluderer man med at nesten all økning i forekomst skyldes mammografiscreening - de antar at den underliggende forekomst av brystkreft har vært stabil (2). Når forskere kommer til så forskjellige resultater, kan det forklares med at det er stor usikkerhet i data. Men det kan også forklares med valg av statistiske metoder. Welch og medarbeidere (2) har gjort enkle analyser og viser at mammografiscreening ikke fører til noe stort fall i forekomst av store svulster (dem som sprer seg og dreper kvinner), men at nesten all økning i kreftforekomst har funnet sted i gruppen med små svulster - svulster som ofte er subkliniske og overdiagnostiserte. På bakgrunn av dette konkluderer de med at det ikke kan være noen stor effekt av mammografiscreening på dødelighet av brystkreft. Dette er et resonnement alle kan følge. Norges forskningsråd rapport er det få som forstår fullt ut. Erfaringsmessig vet man at jo mer komplisert statistikk og studiedesign som man bruker, desto mer sannsynlig er det at resultatene er falskt positive funn eller skjeve (biased) (3).

\section{Per-Henrik Zahl}

per-henrik.zahl@fhi.no

Per-Henrik Zahl (f. 1961) er dr.med. i biostatistikk og arbeider som statistiker ved Divisjon for psykisk og fysisk helse, Folkehelseinstituttet. Han har publisert flere artikler om mammografiscreening og brystkreftdødelighet.

Ingen oppgitte interessekonflikter.

\section{Litteratur}

1. Zahl P-H, Holme $\emptyset$, Løberg M. Norsk mammografiscreening - mange selvmotsigelser $\mathrm{i}$ evalueringen. Tidsskr Nor Legeforen 2016; 136: 1616-8

2. Welch HG, Prorok PC, O'Malley AJ et al. Breast-Cancer Tumor Size, Overdiagnosis, and Mammography Screening Effectiveness. N Engl J Med 2016; 375 $1438-47$.

3. loannidis JPD. Contradicted and initially stronger effects in highly cited clinical research. JAMA 2005; 294: 218-28

I Tidsskriftet nr. 19/2016 presenterte vi en kasuistikk over det første dokumenterte tilfellet av overføring av hepatitt E i Norge.

\section{Re: En pasient i 20 -årene med icterus og smerter i ledd og muskler}

Takk til forfatterne for å presentere en kasuistikk om akutt hepatitt E - en sjelden sykdom i Norge (1). Pasienten hadde et akutt forløp med oppkast, magesmerter, artralgi/myalgi og forhøyet ALAT og i mindre grad ASAT. Han hadde ingen leversvikt, da INR og albumin var innenfor normalområdet. Pasienten hadde bilirubinnivå innenfor normalområdet, men hadde lett icterus i conjunctiva ifølge fastlegen.

Den kliniske observasjonen av icterus var ukorrekt etter min mening. Icterus er klinisk først synlig når bilirubinnivået ligger over $34 \mu \mathrm{mol} / \mathrm{l}$ (2). Selv om icterus best kan oppdages i periferi av conjunctiva under gode lysforhold, kan det også oppdages i slimhinnen under tungen (2).

Emilio Besada

emilio.besada@uit.no 
Emilio Besada (f. 1971) er overlege i revmatologi ved Finnmarkssykehuset i Kirkenes og stipendiat ved og Universitetet i Troms $\varnothing$ - Norges arktiske universitet

Ingen oppgitte interessekonflikter.

\section{Litteratur}

1. Løvdahl A, Øverbø J. En pasient i 20 -årene med icterus og smerter i ledd og muskler. Tidsskr Nor Legeforen 2016; 136: 1651-2.

2. Roy-Chowdhury N, Roy-Chowghury J. Classification and causes of jaundice or asymptomatic hyperbilirubinemia. Uptodate. https://www.uptodate.com/contents/ classification-and-causes-of-jaundice-or-asymptomatic-hyperbilirubinemia? source=search_result\&search=jaundice\&selectedTitle=2 150 (27.10.2016).

I Tidsskriftet $n r .20 / 2016$ spurte T. Madssen \& M. Tufte om man som lege kan titulere seg «dr.» selv om man ikke har doktorgrad. Det har avfødt en del debatt.

\section{Re: Doktor $=$ lege?}

Det er grunn til å knyte ein kommentar til diskusjonen om forkortinga «dr.» for «doktor» i norsk (1). I nynorsk kan ein lege/lækjar kalle seg «dokter», mens «doktor» er for dei som har teke doktorgraden. Innanfor nynorsk rettskriving er dermed «doktor» eintydig.

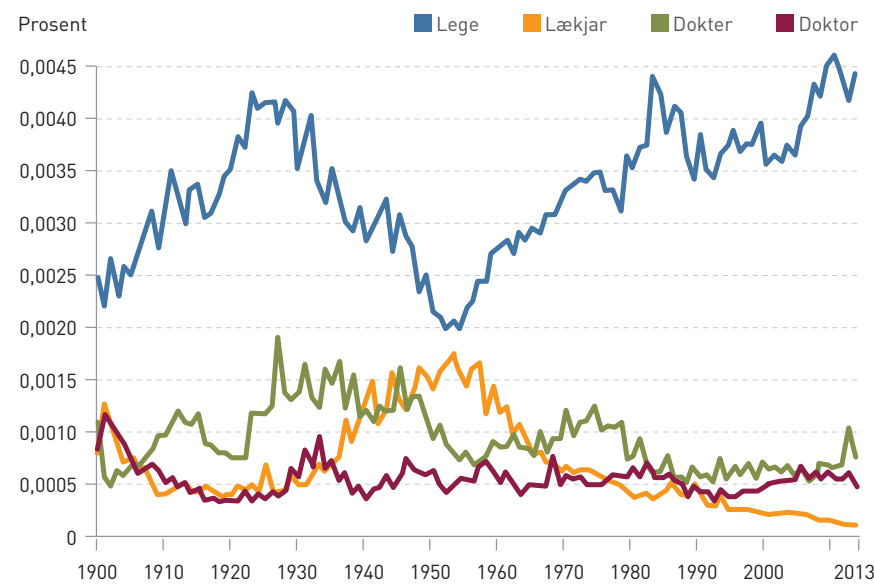

Frekvensen av ordene «lege», «lækjar», «dokter» og «doktor» i nynorske bøker etter 1900. Omtegnet etter tillatelse fra Nasjonalbiblioteket
Eit søk i n-gramtenesta til Nasjonalbiblioteket i nynorske bøker etter 1900 viser at «lege» heile tida har vore det vanlegaste ordet, og at «dokter» har vore noko brukt, men mykje mindre (2).

\section{Marit Hovdenak}

marit.hovdenak@sprakradet.no

Marit Hovdenak (f. 1950) er seniorrågjevar i Språkrådet.

Ingen oppgitte interessekonflikter.

\section{Litteratur}

1. Madssen T. Tufte M. Doktor = lege? Tidsskr Nor Legeforen 2016; 136: 1744

2. Lege, lækjar, dokter, doktor. I: NB N-gram beta. Nasjonalbiblioteket. http://www.nb.no/sp_tjenester/beta/ngram_1/\#ngram/ query?terms $=$ lege $\% 2 \mathrm{C}+1 \% \ldots$ (9.11.2016)

\section{Re: Doktor $=$ lege?}

I Tidsskriftet nr. 20/2016 spør to «tittelforvirra medisinstudentar» om doktor kan brukast synonymt med lege (eller lækjar), og i svaret frå Erlend Hem blir dette stadfesta som rett (1). Så enkelt er det nok ikkje, i alle fall ikkje på nynorsk som er målforma som er nytta av spørsmålsstillarane. På nynorsk tyder doktor ein som har teke den akademiske graden som ein kallar doktorgraden (1). Ein treng m.a.o. ikkje å vera medisinar for å vera doktor. Derimot er ordet dokter (med -e-) synonymt med lege/lækjar (2). Dette svarar godt til uttalen som folk flest brukar om dokter i tydinga lege/lækjar. Men det er vanleg å forkorte både dokter og doktor med dr. På bokmål, derimot, blir doktor (noko overraskande for meg) brukt både om ein som har doktorgrad og om ein som er lege/lækjar (3).

\section{Eiliv Brenna}

eiliv.brenna@stolav.no

Eiliv Brenna (f. 1950) er lege, dr. med. (m.a.o. både dokter og doktor). Ingen oppgitte interessekonflikter.

\section{Litteratur}

1. Madssen T. Tufte M. Doktor = lege? Tidsskr Nor Legeforen 2016: 136: 1744.

2. Alf Hellevik. Nynorsk ordliste. 10. utg. Oslo: Samlaget, 2011.

3. Bokmålsordboka. 2. utg. Oslo: Kunnskapsforlaget, 1997. 